\title{
desgaste de las placas de blindaje en los tubos moledores
} verschleiss von mantelplatten in rohrmühlen F. MATONSCHEK

(«Zement-Kalk-Gips», 13, núm. 9, septiembre 1960, pág. 394.)

Se discute la duración de las placas de blindaje y se comparan varias fórmulas de la estadística matemática, métodos gráficos y apreciaciones prácticas.

Resulta un «límite de confianza» de $\pm 20 \%$.

En el caso de la molturación de materias primas por vía seca, la vida de las placas es de 90.000 a 130.000 horas aproximadamente. El manganeso es más adecuado que el cromo como constituyente de la aleación.

En el caso de la molturación de materias primas por vía húmeda la vida es de unas 10.000 horas. Ensayos sistemáticos permitirán realizar una gran mejora.

En la molienda de cemento la duración de las placas de acero austenítico al manganeso en la primera cámara es de 11.700 horas. En este caso, también se ha encontrado que el cromo es inferior al manganeso como metal de aleación. Las aleaciones al níquel son frágiles. El acero C2DL150 se comporta bien, con una duración de 26.300 horas. Empleando placas con resaltes (tetones) se observa un aumento considerable en la vida de la placa, la cual oscila de 20.000 a 50.000 horas. Mediante un control riguroso del desgaste por fotos periódicas, medida del espesor y pesada, pueden eliminarse o, al menos, reducirse, los fracasos.

En la segunda cámara de molienda la vida media es de 19.200 horas. Las placas rómbicas hechas de acero RC-C2F han resultado especialmente satisfactorias; en este caso, la aleación empleada contribuyó mucho más a la mejora que la forma de la placa.

Se hace un estudio de la durabilidad de las placas en molinos con circuito cerrado.

De todos estos resultados puede deducirse la conclusión de que la solución ideal es buscar un efecto combinado de la aleación y la forma de la superficie de las placas, y este camino será probablemente el más afortunado.

De importancia igualmente decisiva son, sin embargo, el cuidado llevado en la fabricación de las placas y la activa cooperación del usuario, quien puede dar ideas muy valiosas al fabricante y contribuir sustancialmente a mejorar las placas de blindaje. 